\title{
DRAVING UP A BUDGET USING THE ACTIVITY BASED BUDGETING METHODOLOGY THROUGH THE SIMULATION OF PROCESSES
}

\author{
DITA JANÍKOVÁ
}

\section{INTRODUCTION}

In the past years, the area of budgeting has undergone significant changes in the same way as other managerial and economic tools. In today's business practice, budgeting is considered very important because of its ability to plan and control the development of economic indicators of companies and to perform responsibility controls of executives at all management levels (Popesko, 2009). Moreover both the theoretical and empirical results suggest that organizational budgetary processes do not provide similar understanding of budget targets for each person (Kihn, 2011). It is a pity that it has not been fully connected with the company's quality management - after all, these two areas should go hand in hand because the correctly implemented quality system guarantees that customers will get perfect and high-quality products with the required features while the company keeps their production costs to a minimum. The other side of the quality definition is often neglected in practice and the economics of quality are somewhat omitted. The purpose of this paper is, through a simple example, to show how production costs of individual products can be realistically specified using the simulation of processes, including poor quality costs, and how to draw up a budget of the whole process. $\mathrm{ABC}$ (Activity Based Costing) and $\mathrm{ABB}$ (Activity Based Budgeting) methods and MS Excel, where a simple simulation of processes will be made, will be used.

Traditional methods of drawing up budgets are often one of main reasons of ineffective company resource management. The main disadvantages of traditional budgets are as follows:

- The main problem is time perspective: nowadays, the budget lifecycle does not correspond to the turbulent environment of companies at all, and mostly, this data loses its topicality before it takes effect (drawing up budgets usually starts in September and they are approved in December). And changes of the budget are unacceptable after being approved.

- Mostly, budgets are not coherent - so various kinds of plans which do not form a consistent complex coexist in companies. 
- Cause-and-effect relationships between the indicators measuring business objects and processes are not sufficiently used in planning models; moreover, there is no clear definition of ways to reach the objective.

- Budgets suppress opportunities to use synergetic effects between divisions because each division tends to protect its activities (and thereby finances) while they could come together and for example, use their facilities better, create new business opportunities etc.

- In most cases, nobody is concerned about the real core and usefulness of overhead expenses spent.

- It often happens that at the beginning of the year, executives save, and at the end of the year, they hastily spend budget means because they are rewarded according to budget fulfilment (i.e. sanctions for its exceeding on one hand and decreasing the budget for the next year when the finances are not withdrawn, especially in the area of overhead expenses, on the other hand).

- Division managers usually endeavour to justify the centre's current budget, and top managers usually give in to this pressure since they do not have any possibility to verify the eligibility of these requirements. Thus, budget chains of individual years that differ only in the amount of costs of partial items are drawn up, and in total, they have a permanent tendency to grow (Popesko, 2009).

These shortcomings had brought the necessity to search for more effective ways of budget planning; thereafter, some firms set out on a radical journey and entirely ceased to draw up traditional budgets, introducing more flexible and effective systems for planning and evaluating costs and revenues; the most popular are for example Beyond Budgeting, Zero-Based Budgeting - Popesko (2009) for example, presents more information about these methods - or Activity-Based Budgeting, hereinafter referred to as ABB.

\section{METHODOLOGY}

As its name suggests, this method is closely connected with the calculations according to $\mathrm{ABC}$ activities; as a matter of fact, it concerns the application of these principles to the area of budgeting. Activity-based costing (ABC) data have the potential to inform a widerange of management decisions (Partridge \& Perren, 1998). Thus, plans and budgets are drawn up on the basis of the expected consumption of performance of individual activities and we are able to measure them by real performance units. The whole budget is then naturally more comprehensible at all the company's organisational structure levels. Basic phases of $\mathrm{ABB}$ drawing up will be clarified using an example from the area of aviation, specifically a catering firm, which delivers meals according to the requirements of individual customers on board airplanes. The objective is to determine a 
budget of delivery processes for a concrete customer $Z$, to specify the effectiveness of the processes and to quantify wasting.

First, data about the process must be available:

a) How the process works - a process scheme is made (MS Visio is used for drawing) on the basis of documents and observing the real process. The process scheme is mentioned in Figure 1 (see below).

b) A list of customers and their withdrawals - at the moment, we are interested only in customer Z.

Table 1 - Overview of customers and their withdrawals

\begin{tabular}{|c|c|c|c|}
\hline Customer & $\begin{array}{c}\text { Number of } \\
\text { meals per month }\end{array}$ & Of which J (Business Class) & Of which Y (Economy Class) \\
\hline $\mathrm{XY}$ & 50,000 & 6,000 & 44,000 \\
\hline $\mathrm{Z}$ & 12,000 & 1,500 & 10,500 \\
\hline $\mathrm{AB}$ & 10,000 & 2,000 & 8,000 \\
\hline $\mathrm{CD}$ & 200 & $\mathrm{x}$ & 200 \\
\hline
\end{tabular}

It results from the table that the customer $\mathrm{Z}$ withdraws $16.6 \%$ of the total number of delivered products.

c) Traditional Calculation - used uniformly for all customers

Table 2 - Traditional calculation used

\begin{tabular}{|l|r|r|r|r|r|}
\hline $\begin{array}{c}\text { Menu } \\
\text { description }\end{array}$ & $\begin{array}{c}\text { Ingredients } \\
\text { costs } \\
\text { (variable) } \\
{[C Z K]}\end{array}$ & $\begin{array}{c}\text { Direct, } \\
\text { personnel } \\
\text { and other } \\
\text { fixed costs } \\
\text { [CZK] }\end{array}$ & $\begin{array}{c}\text { Gross margin } \\
\text { within the volume } \\
\text { of } 60,000 \text { meals } \\
\text { (fixed) } \\
\text { [CZK] }\end{array}$ & $\begin{array}{c}\text { Price per } \\
\text { menu in } \\
\text { total } \\
\text { [CZK] }\end{array}$ & $\begin{array}{c}\text { Selling } \\
\text { price per } \\
\text { menu } \\
\text { [CZK] }\end{array}$ \\
\hline Hot meal J & 86.12 & 4.78 & 19.32 & 110.22 & 150 \\
\hline Hot meal Y & 31.94 & 3.06 & 19.32 & 54.32 & 65 \\
\hline
\end{tabular}

Now, we start to analyse the costs for individual processes. We divide the costs into:

a) Direct costs, namely those which are connected as resources to individual processes and according to the period of process duration - namely times of using the concrete resource; their amount can be easily calculated.

b) Indirect or overhead costs that must be divided into individual processes for which we use the $\mathrm{ABC}$ method. 


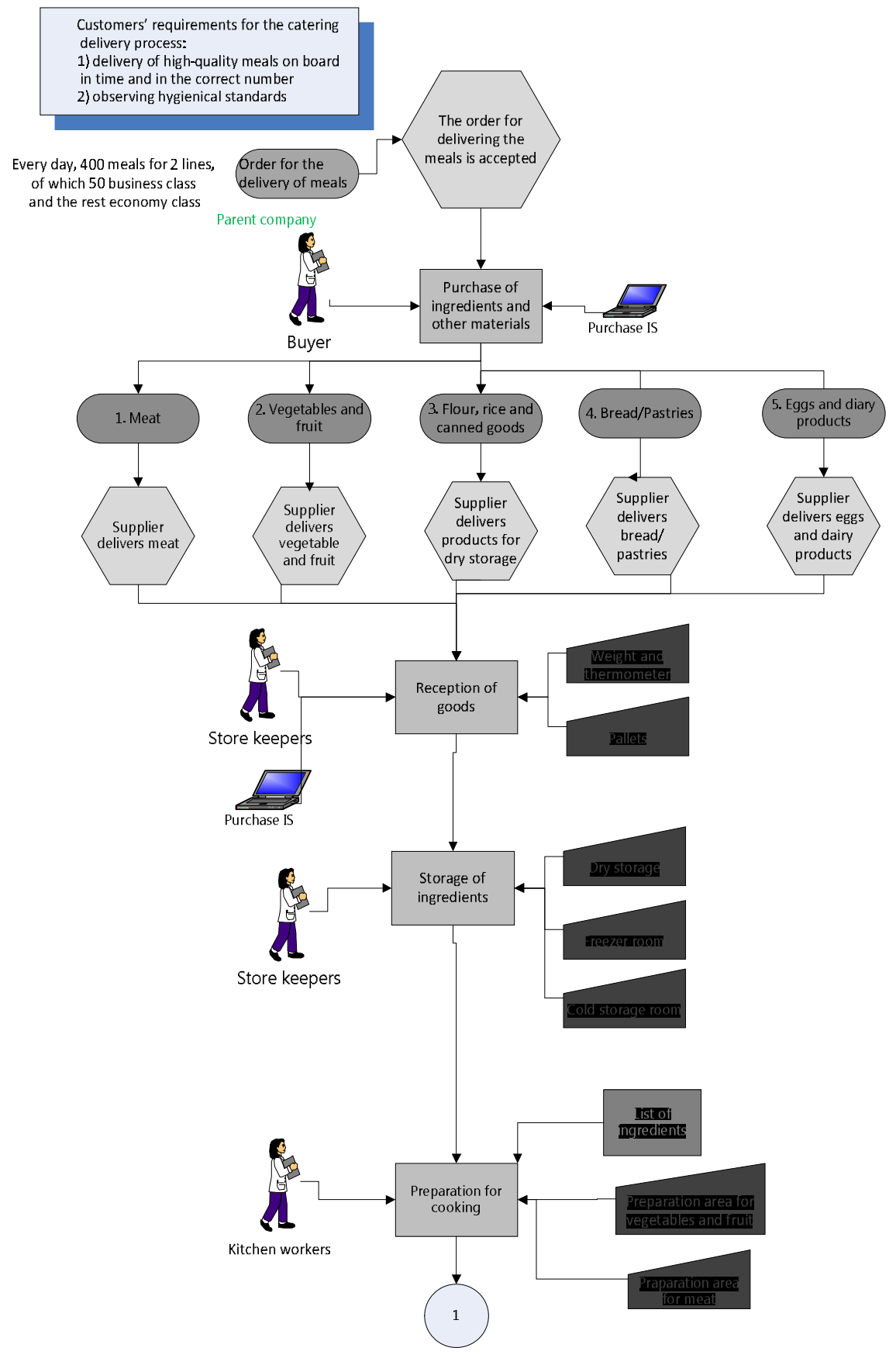

Figure - 1 Process model for catering deliveries to airplanes (part 1) 


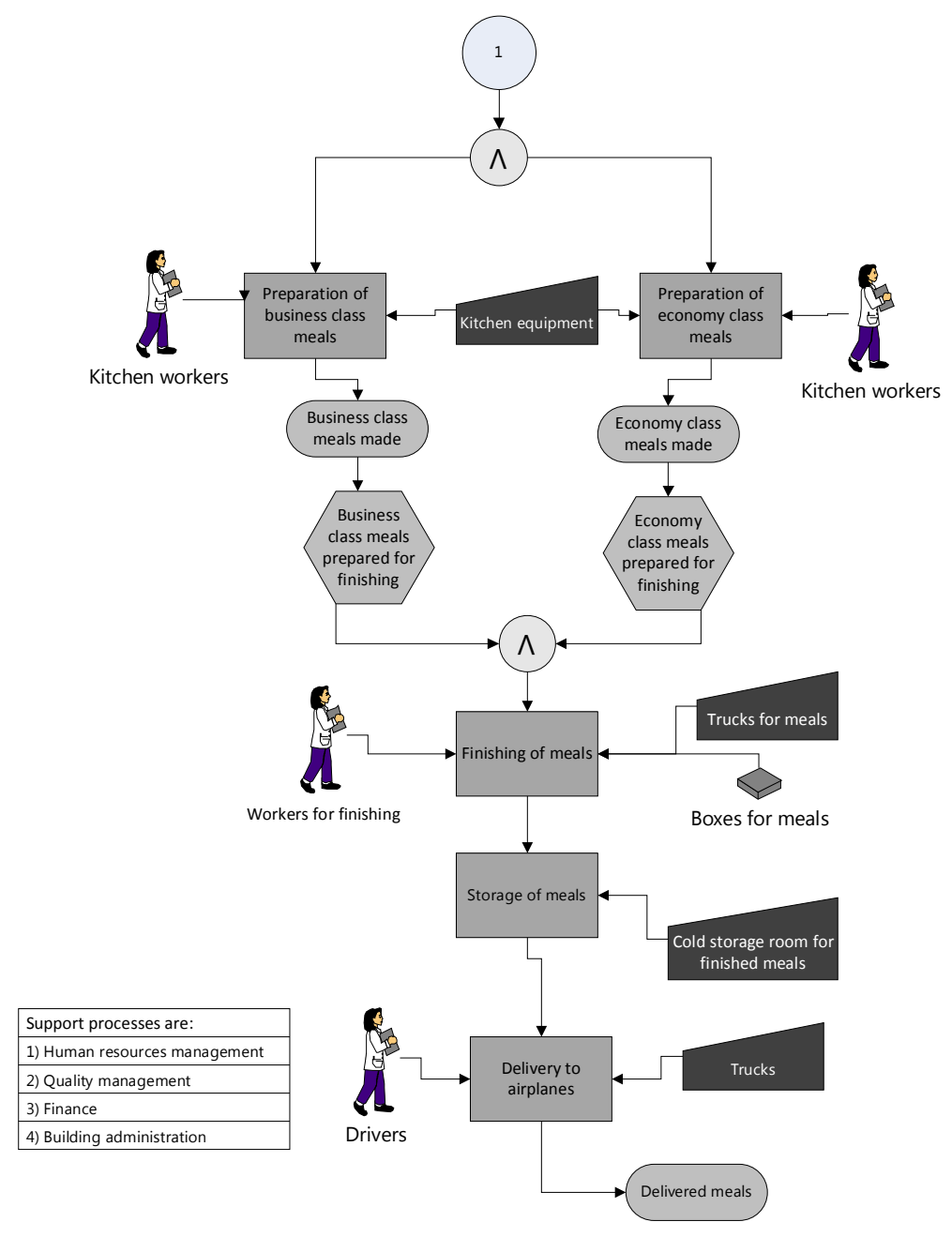

Figure - 1 Process model for catering deliveries to airplanes (part 2)

\section{STEP 1: Direct costs determination}

First, it is necessary to have general knowledge of the costs for individual resources as well as of the lead time of individual processes to be able to calculate direct costs of processes. This value is a random variable which will be subject to the later simulation of processes. The process lead time is calculated per one entity's (i.e. an order's) passage through the process for one resource, thus, for example the preparation of $\mathrm{J}$ meals takes 1 hour a day, however, 4 workers work on it.

The result of process lead time determination and possible variances is mentioned in the following table: 
Table 3 - Process lead time and variances

\begin{tabular}{|c|c|c|c|c|c|c|c|}
\hline $\begin{array}{l}\infty \\
0 \\
0 \\
0 \\
0 \\
0\end{array}$ & 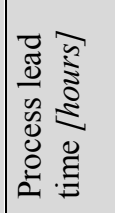 & 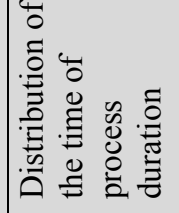 & 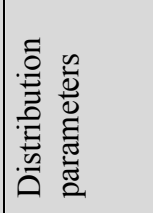 & 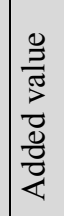 & 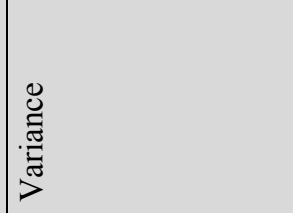 & 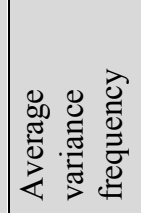 & 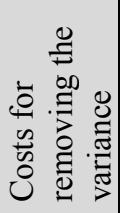 \\
\hline \begin{tabular}{|l}
$\begin{array}{l}\text { Purchase of } \\
\text { ingredients }\end{array}$ \\
\end{tabular} & 0.25 & normal & $\begin{array}{l}X=0.25 \\
S=0.0833 \\
\end{array}$ & yes & & & \\
\hline $\begin{array}{l}\text { Reception } \\
\text { of goods }\end{array}$ & 13.3 & normal & $\begin{array}{l}\mathrm{X}=13.3 \\
\mathrm{~S}=1\end{array}$ & yes & $\begin{array}{l}\text { Required goods are } \\
\text { not delivered or they } \\
\text { are not delivered in } \\
\text { the satisfactory } \\
\text { quality }\end{array}$ & week & 00 \\
\hline \begin{tabular}{|l} 
Storage of \\
ingredients
\end{tabular} & 24.0 & normal & $\begin{array}{l}X=24 \\
S=5\end{array}$ & no & $\begin{array}{l}\text { Expired goods in } \\
\text { stock }\end{array}$ & ay & 300 \\
\hline $\begin{array}{l}\text { Preparation } \\
\text { for cooking }\end{array}$ & 3.0 & normal & $\begin{array}{l}X=3 \\
S=0.2\end{array}$ & yes & & & \\
\hline \begin{tabular}{|l|} 
Preparation \\
of J meals
\end{tabular} & 4.0 & normal & $\begin{array}{l}X=4 \\
S=0.2\end{array}$ & yes & Spoiled meals, waste & $1 \mathrm{x}$ day & 000 \\
\hline $\begin{array}{l}\text { Preparation } \\
\text { of Y meals }\end{array}$ & 3.0 & normal & $\begin{array}{l}X=3 \\
S=0.2\end{array}$ & yes & Spoiled meals, waste & $1 \mathrm{x}$ day & 500 \\
\hline $\begin{array}{l}\text { Finishing of } \\
\text { meals }\end{array}$ & 2.0 & normal & $\begin{array}{l}X=2 \\
S=0.1\end{array}$ & yes & $\begin{array}{l}\text { Incorrect indication } \\
\text { of meals - exchange } \\
\text { of lines. }\end{array}$ & $\begin{array}{l}1 \mathrm{x} \\
\text { month }\end{array}$ & 5,000 \\
\hline $\begin{array}{l}\text { Storage of } \\
\text { meals }\end{array}$ & 0.33 & normal & $\begin{array}{l}X=0.33 \\
S=0.0822\end{array}$ & yes & & & \\
\hline $\begin{array}{l}\text { Delivery to } \\
\text { airplanes }\end{array}$ & 2.0 & normal & $\begin{array}{l}\mathrm{X}=2 \\
\mathrm{~S}=0.2\end{array}$ & yes & $\begin{array}{l}\text { Late delivery of } \\
\text { meals - contractual } \\
\text { penalty }\end{array}$ & $\begin{array}{l}2 \mathrm{x} \\
\text { month }\end{array}$ & 30,000 \\
\hline
\end{tabular}

*Here, the storage of meals has added value since for reasons of cooling, it is necessary to cool down the meals for required temperature $\left(8^{\circ} \mathrm{C}\right.$ according to the ITCA standard).

Now, the quantification of personnel (see the Table 4) and other resources (see the Table 5) must be made:

Table 4-Personnel quantification overview

\begin{tabular}{|l|r|r|r|r|}
\hline Position & $\begin{array}{l}\text { Wages \& social } \\
\text { and health } \\
\text { insurance } \\
\text { (CZK per month) }\end{array}$ & $\begin{array}{l}\text { Rewards, employee } \\
\text { benefits } \\
\text { (CZK per month) }\end{array}$ & $\begin{array}{l}\text { Costs for } \\
\text { uniforms and } \\
\text { work aids } \\
\text { (CZK per month) }\end{array}$ & $\begin{array}{l}\text { Training costs } \\
\text { (CZK per year) }\end{array}$ \\
\hline Buyer & 33,000 & 3,000 & 100 & 1,000 \\
\hline Store keeper & 18,000 & 3,000 & 100 & 300 \\
\hline Kitchen worker & 18,000 & 2,000 & 100 & 500 \\
\hline Finishing worker & 15,000 & 2,000 & 100 & 1,000 \\
\hline Driver & 16,000 & 3,000 & & \\
\hline
\end{tabular}


Table 5 - Resource quantification overview

\begin{tabular}{|l|r|l|l|l|}
\hline Resource & $\begin{array}{l}\text { Price for } \\
\text { maintenance } \\
\text { (CZK per month) }\end{array}$ & $\begin{array}{l}\text { Depreciation } \\
\text { costs } \\
\text { (CZK per month) }\end{array}$ & $\begin{array}{l}\text { Frequency } \\
\text { of failure } \\
\text { occurrence }\end{array}$ & $\begin{array}{l}\text { Costs for } \\
\text { removing the } \\
\text { failure (CZK) }\end{array}$ \\
\hline $\begin{array}{l}\text { Cold storage } \\
\text { room }\end{array}$ & 500 & 300 & $0.2 *$ month & 500 \\
\hline Freezer & 500 & 400 & $0.5 *$ month & 600 \\
\hline Dry storage & 100 & & & \\
\hline
\end{tabular}

Note to Table 3,4,5: In our example, we disregard resources such as pallets, thermometers and others, which are also used in the process, for reasons of clarity.

By simple multiplication of the lead time and resource costs in the given process, we determine direct costs and thus we can proceed to dividing the indirect costs using a matrix of costs.

\section{STEP 2: Indirect costs determination}

See the Matrix of Cost Classification in the Table 6.

\section{STEP 3: Drawing up a simulation model}

Now, the process simulation will be made on the basis of the process model and received data; naturally with regard to MS Excel restrictions.

The lead time of the process duration in individual days and the amount of classified costs (according to the matrix of costs - see Table 7), as well as the occurrence of eventual variances (see Table 3), are random variables. Each process can include 3 figures: direct costs determination, indirect costs determination and possible occurrence of variance:

1) The columns for determination of costs according to the process duration and indirect costs determination. Both are random variables generated as follows:

ROUNDUP (NORMINV ( (RANDBETWEEN ( $1 ; 99) / 100)$; mean value; standard deviation);0).

2) The occurrence of variances is simulated according to the following condition:

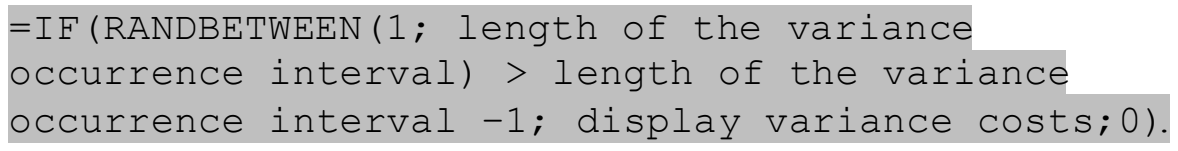

Average process variance costs can be specified in a qualified way, or - if the variances did not generate only costs but also the time for their removal - we can add the given occurrence to the total process lead time. 
In the first phase, we determine how many support processes we "use" for customer Z:

1) We start with support processes (Table 6) first, we divide them into logical groups to divide the costs more easily.

2) We classify the costs in individual groups recorded in the accounting.

3) If we have more customers/we produce more types of products then we choose a method of dividing individual costs into the given customer/product; in this case, it is pro rata according to the number of products withdrawn (Table 6).

In the second phase, we associate these costs of support processes according to a parameter related to individual processes in the model.

1) We continue with the processes in the model; in the same way as with the support processes, we classify remaining costs for the process from the accounting; we naturally leave out the direct costs that have already been classified.

2) Using related parameters, we classify a proportional part of costs from the support processes (Table7).

Now we can use data from matrix to make a simulation of the result amount (Table 8).

The final calculation is as follows:

Costs per $1 \mathrm{~J}$ meal are: $\quad 208 \mathrm{CZK} \quad \ldots$ their original calculation was $110 \mathrm{CZK}$

Costs per $1 \mathrm{Y}$ meal are: $\quad 31 \mathrm{CZK} \quad \ldots$ their original calculation was $54 \mathrm{CZK}$

It follows that the costs for the preparation of $\mathrm{J}$ meals have been undervalued and on the contrary, the costs for the preparation of Y meals have been overvalued.

When drawing up a budget according to $\mathrm{ABB}$, the process is as follows:

1) Strategy analysis - in this phase, we define critical success factors for each of the formulated strategies - for example, increasing the satisfaction of customers - and then, we determine measurable parameters for this factor. In our case, these are: timely deliveries and high-quality meals which customers consider delicious and that are suitable for consumption. 
2) Value chain analysis - we explore what activities and processes correspond to defined strategies and which are not significant from this point of view; eventually they do not create value perceived by a customer. In our example, the processes are set in compliance with the strategy; with regard to renting trucks that deliver meals to airplanes, I recommend considering the possibility of the total outsourcing of this process. Try another simulation.

3) Working load forecast - we identify the load volume of employees performing individual activities on the basis of the specified number of products. According to the contract, customer $\mathrm{Z}$ will buy 12,000 meals a month next year, of which 1,500 will be J meals and 10,500 Y meals.

4) Planning instructions - factors specified by the management or another competent body regarding the supposed inflation, interest rates, growth dynamics, and eventually other external factors are included here.

5) Analysis of investments in activities - investments in activities specify their cost structure. It is important to consider this, especially in the area of depreciation costs and efficiency of processes. It will be necessary to reconstruct the cold kitchen which has a very high room temperature unsuitable for the hygienic requirement of $8^{\circ} \mathrm{C}$ (according to ITCA) next year. The costs will be CZK 450,000, calculated according to the number of meals bought: for customer Z, it is CZK 74,700.

6) Activity-level analysis - specifying the rate of activity performance to determine unit costs for each activity (in the case that we have an actual $\mathrm{ABC}$ model, this step is useless). See the table of cost classification.

7) Calculation of costs for processes and products - we specify the expected future consumption of activity units. Simply by multiplying the number of $\mathrm{J}$ and $\mathrm{Y}$ meals bought, it is: CZK 637,500 a month; for more detailed budgets for individual resources and processes, see the table of costs. Furthermore, the investment costs, i.e. CZK 74,700, and corrections according to point 4 , must be added. In the end, it can be said that the rate of non-productive costs (i.e. variances and time not adding any value) is high (59\%) and a strategy leading to the elimination of waste and significant decrease of variances must be prepared.

8) Budget specification - then, we have a sufficient amount of information to draw up a budget; it can be constructed in more variations, and it can offer modelling scenarios for future development. 


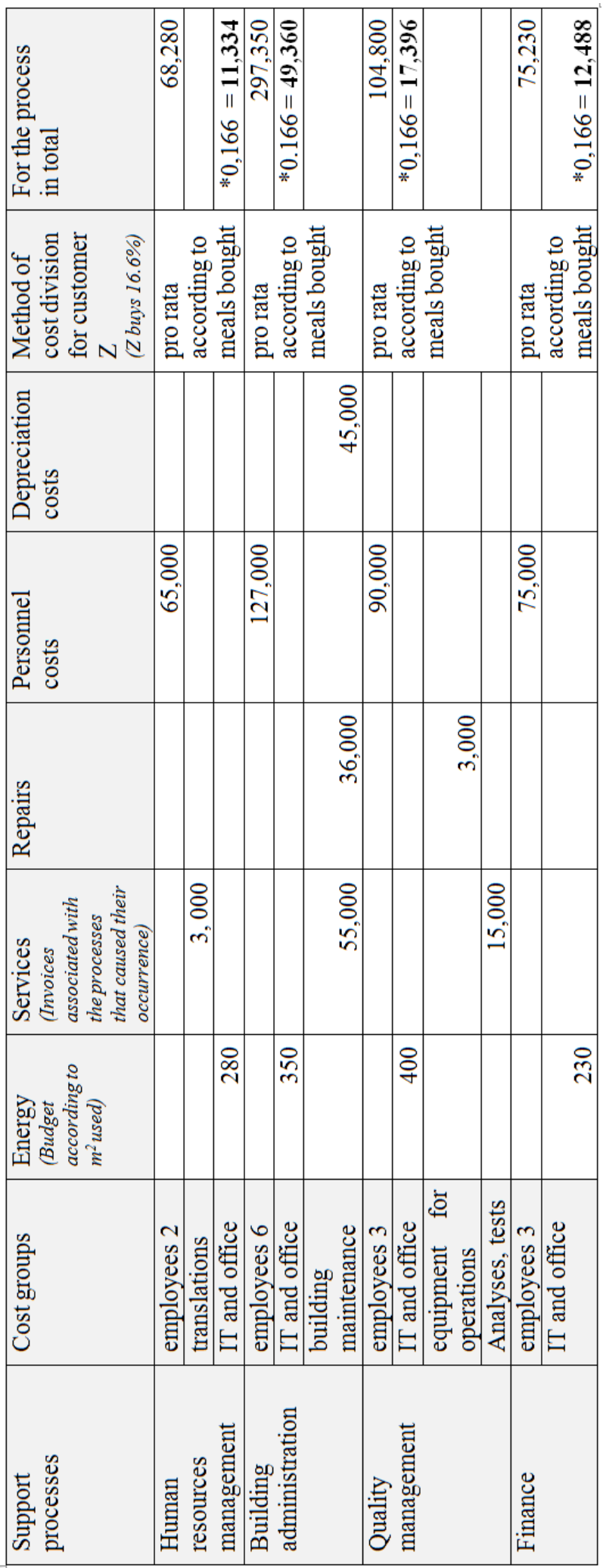




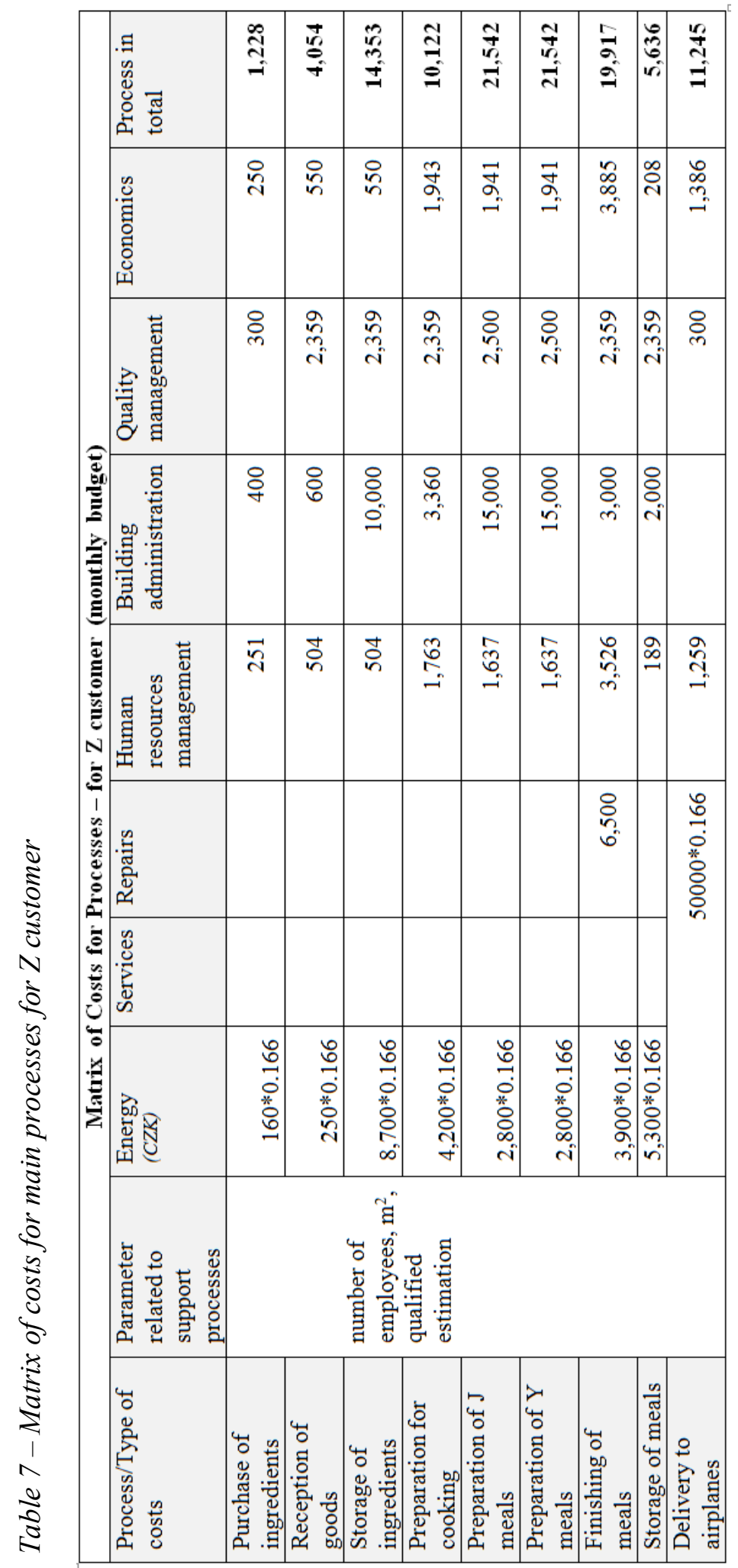




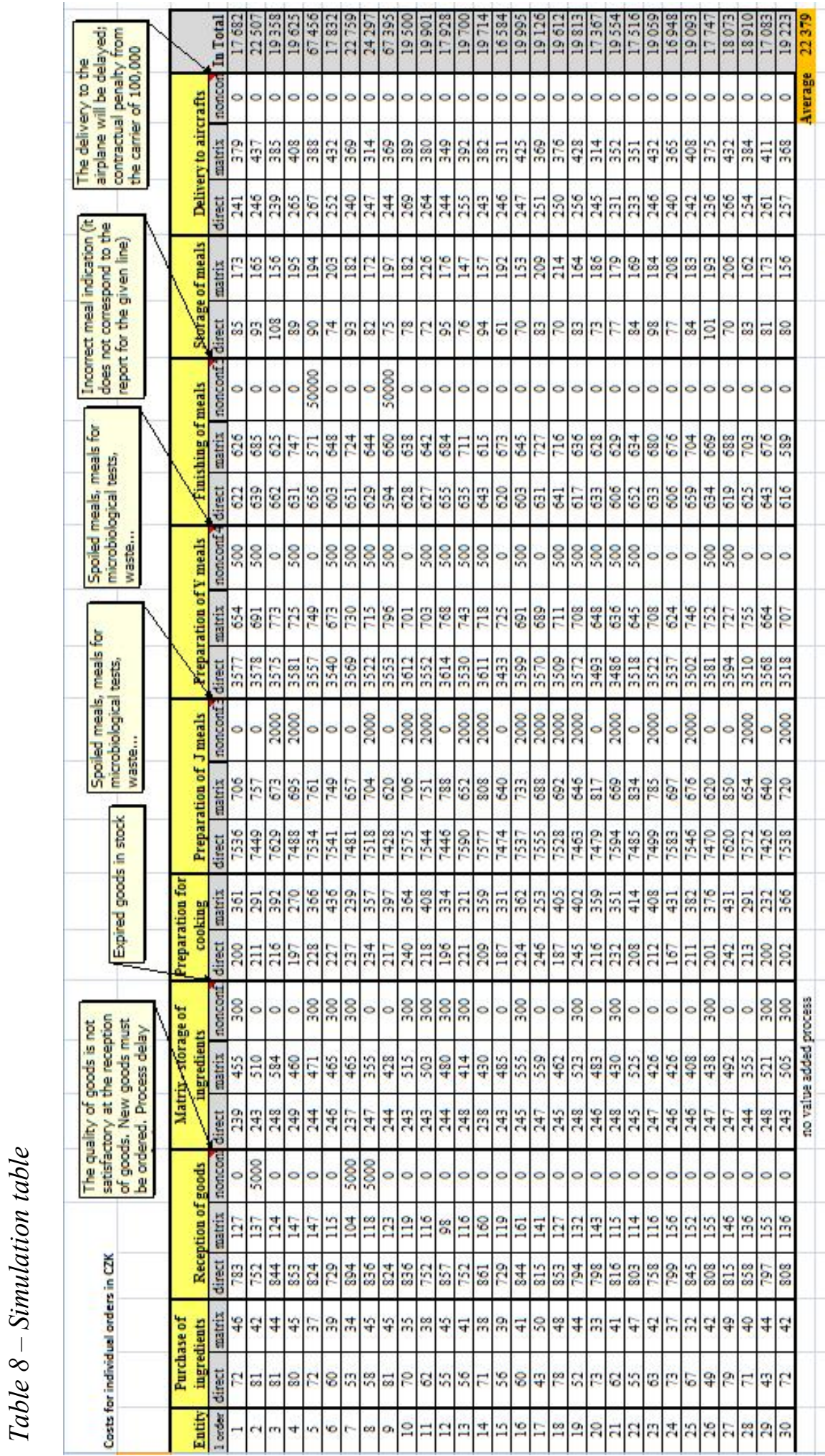




\section{CONCLUSION}

In this example, especially the interconnection of typically financial processes, such as calculations of product costs or building up a budget, with the system of quality management in the area of the analysis of processes and observing costs for poor quality is interesting. It is apparent that even the calculations used over a long period of time were absolutely different after the accurate calculation of the real consumption of product costs compared to their long-time use, and business class meals were entirely unprofitable. Interconnecting the analysis of processes with the budget drawing up is also interesting - i.e. during the very budgeting process, we specify if the process continues like this or we determine optimisation measures. Costs for variances and non-productive time such as waiting or product storage are hardly ever considered in the calculation of process/product costs and in budgets. By simulating the process, we will get a far more realistic view of the process and products, and moreover, we can directly define weak points and possibilities for change in processes, and determine on which variances we should focus improvement projects when working out a budget.

\section{REFERENCES}

Kihn, L. A. (2011). "How Do Controllers and Managers Interpret Budget Targets?", Journal of Accounting \& Organizational Change, Vol. 7, Issue 3, pp. 212 - 236.

Partridge, M., Perren, L. (1998). "An integrated framework for activity-based decision making”, Management Decision, Vol. 36 Issue 9, pp. 580 - 588

Popesko, B. (2009). Moderní metody rízení nákladi (Modern methods of cost control), $1^{\text {st }}$ edition, Prague: Grada Publishing, a.s., p. 240, ISBN 978-80-2472974-9

\section{ABOUT THE AUTHOR}

Ing. Dita Janíková, worked as Projec Manager in Czech Airlines.

e-mail: dita.beyrova@email.cz 